\begin{tabular}{|l|l|l|l|l|l|}
\hline J. Tek. Ling & Vol. 13 & No. 1 & Hal. $101-108$ & Jakarta, Januari 2012 & ISSN 1441-318X \\
\hline
\end{tabular}

\title{
ISOLASI, POPULASI DAN KARAKTERISASI BAKTERI PELARUT FOSFAT PADA DAERAH PERAKARAN DAN TANAH DARI BENGKULU, SUMATRA
}

\author{
Sri Purwaningsih
}

Peneliti di Bidang Mikrobiologi, Puslit Biologi-LIPI, Bogor

JIn Raya Jakarta-Bogor Km 46 CSC Cibinong, Jawa Barat

\begin{abstract}
Abstrak
Penelitian dilakukan untuk mengetahui isolasi, populasi dan karakterisasi bakteri pelarut fosfat pada tanah dari rizosfer tanaman dari Bengkulu, Sumatra. Tujuan penelitian untuk mengetahui populasi bakteri pelarut fosfat dari rizosfer tanaman, dan mendapatkan kultur murni. Sampel diambil dari 25 sampel tanah dari rizosfer tanaman. Isolasi dilakukan dengan metode dilusi dalam Pycosvkaya menengah standar, inculation di $\left(27-28^{\circ} \mathrm{C}\right)$ setelah 15 hari, dan penduduk dengan metode plate count. Populasi bakteri pelarut fosfat berada di kisaran 13-101 $10^{5} \mathrm{X}$ tanah CFU / g, dan populasi tertinggi ditemukan dari sampel tanah dari rhizoaphere dengan Semangka (Citrulus lanatus) tanaman. Tujuh puluh lima memberikan budaya murni. Karakteristik pertumbuhan kultur murni diamati dengan menggunakan media Pycosvkaya. Inkubasi di $\left(27-28^{\circ} \mathrm{C}\right)$ setelah 15 hari. Zona jelas mengelilingi koloni menunjukkan bahwa fosfat dalam medium adalah terhidrolisis dan zona terbentuk dari dua hari sampai delapan hari
\end{abstract}

kata kunci: Bakteri pelarut Fosfat, Pycosvkaya, Bengkulu

\begin{abstract}
The research was conducted in order to know the isolation, population and characterizations of phosphate solubilizing bacteria on the soil from rhizosphere plants from Bengkulu, Sumatra. The purpose of the study to know the population of phosphate solubilizing bacteria from rhizosphere plants, and the get pure culture. The sample was taken from 25 sample soil from rhizosphere of plants. Isolation was done with dilution methods in standard medium Pycosvkaya, the inculation at $\left(27-28^{\circ} \mathrm{C}\right)$ after 15 days, and the population with plate count methods. The population of phosphate solubilizing bacteria was in the range of $13-101 \times 10^{5} \mathrm{CFU} / \mathrm{g}$ soil, and the highest population was found from the sample soil from rhizoaphere with Semangka (Citrulus lanatus) plant. Seventy five gave of pure culture. The growth characteristic of pure culture was observed by using Pycosvkaya medium. Incubation at $\left(27-28^{\circ} \mathrm{C}\right)$ after 15 days. The clear zone surround the colonies indicate that the phosphate in the medium was hydrolyzed and the formed zone from two days until eight days
\end{abstract}

key words: Phosphate Solubilizing Bacteria, Pycosvkaya, Bengkulu 


\section{PENDAHULUAN}

\subsection{Latar belakang}

Bengkulu merupakan salah satu Propinsi di Sumatra yang berbatasan langsung dengan Samodra India, bagian Barat merupakan dataran rendah yang sempit, sedangkan bagian Timur merupakan dataran tinggi yang berbukit-bukit dan tanahnya subur. Kawasan seperti ini memiliki nilai keanekaragaman hayati yang cukup tinggi. Usaha untuk menggali sumber daya hayati sudah banyak dilakukan, namun untuk jenis mikrobanya, terutama mikroba tanah belum banyak informasi yang diungkapkan, sehingga perlu dilakukan eksplorasi mengenai jenis mikroba tersebut diatas, terutama jenis bakteri tanahnya. Eksplorasi dilakukan dengan cara mengambil contoh tanah dari daerah perakaran yang disebut dengan daerah rhizosfer. Daerah rizosfer merupakan bagian dari tanah yang memiliki aktivitas metabolisme tertinggi yang langsung dipengaruhi oleh pertumbuhan dan metabolisme akar tanaman. Tanaman dan mikroorganisme berinteraksi dan saling menstimulasi yang disebabkan oleh adanya eksudat akar. Sedangkan eksudat akar akan mempengaruhi pertumbuhan dan aktivitas mikroorganisme di daerah rizosfer, rizoplan dan sekitarnya ${ }^{1,22}$.

Untuk mengetahui dan meningkatkan tingkat kesuburan tanah dan produktivitas lahan di kawasan Bengkulu perlu didukung data dan informasi tentang bakteri tanah. Salah satunya adalah bakteri pelarut fosfat. Bakteri pelarut fosfat merupakan jasad renik tanah yang mempunyai kemampuan melepaskan ikatan $\mathrm{P}$ dan berperan dalam melarutkan $\mathrm{P}$ yang tidak tersedia menjadi tersedia, sehingga dapat digunakan oleh tanaman untuk tumbuh dan berkembang ${ }^{3)}$, dan meningkatkan penyerapan $\mathrm{P}$, sehingga dapat meningkatkan ketersediaan unsur $\mathrm{P}$ terutama pada tanah-tanah masam ${ }^{4}$. Selain itu mikroorganisme pelarut $P$ ini akan menghasilkan asam-asam organik yang mampu mengkhelat $\mathrm{Al}, \mathrm{Fe}, \mathrm{Ca}$, dan
Mg membentuk komplek organometal yang stabil dan $\mathrm{P}$ menjadi tersedia bagi tanaman dan sebagai pelarut fosfat anorganik yaitu sebesar $10^{4}-10^{6} \mathrm{sel} / \mathrm{g}$ tanah dan sebagian besar pada daerah perakaran ${ }^{5)}$, serta mampu memacu pertumbuhan tanaman karena menghasilkan zat pengatur tumbuh dan menahan penetrasi patogen akar, hemat energi, dan tidak mencemari lingkungan ${ }^{6}$. Jenis-jenis mikroba tersebut adalah Penicillium sp ${ }^{7}$, Bacillus sp. ${ }^{8}$, , Pseudomonas $\mathrm{sp}^{9)}$ dan lain sebagainya. Mikroba tersebut mempunyai kemampuan melarutkan mineral-mineral fosfat melalui sekresi asam organik ${ }^{10)}$ dan melibatkan enzim fosfatase, serta berperan dalam menstranfer energi, menyusun protein, koenzim, asam nucleat dan senyawa-senyawa metabolik lain, sehingga dapat menambah aktivitas penyerapan $\mathrm{P}$ pada tumbuhan yang kekurangan $\mathrm{P}^{11)}$, Laju pertumbuhan tanaman Lamtoro meningkat setelah diberi bakteri pelarut fosfat ${ }^{9)}$, namun dalam prakteknya bakteri pelarut fosfat dalam melarutkan unsur $P$ yang terikat, sangat berkaitan erat dengan cara beradaptasi dari bakteri tersebut dengan lingkungannya. Lingkungan yang baik dan cocok untuk jenis bakteri pelarut fosfat tertentu akan meningkatkan aktivitasnya dalam mengeluarkan asamasam organik, enzim dan hormon-hormon tumbuh untuk melarutkan unsur $\mathrm{P}$ di dalam tanah $^{12)}$ Sebagai upaya untuk mengetahui keberadaan bakteri pelarut fosfat tersebut diatas, maka dilakukan inventarisasi dan isolasi, serta mengetahui populasi bakteri tersebut, dengan harapan akan didapatkan bakteri yang efektif dan potensial, yang nantinya dapat dikembangkan sebagai pupuk hayati guna meningkatkan kesuburan tanah.

Tujuan dari penelitian ini adalah untuk mengetahui keberadaan bakteri pelarut fosfat, dan untuk mendapatkan isolat murni yang potensial, yang nantinya dapat dikembangkan sebagai pupuk hayati guna meningkatkan kesuburan tanah, terutama di daerah Bengkulu. 


\section{METODOLOGI}

\subsection{Bahan}

Sampel tanah dari kedua desa tersebut diatas dilakukan isolasi. Media yang digunakan adalah media Pycosvkaya ${ }^{13)}$ yang terdiri atas: $\mathrm{Ca}_{3}\left(\mathrm{PO}_{4}\right)_{2} 5 \mathrm{~g},\left(\mathrm{NH}_{4}\right)_{2} \mathrm{SO}_{4}$ $0,5 \mathrm{~g}, \mathrm{NaCl} 0,2 \mathrm{~g}, \mathrm{MgSO}_{4} 7 \mathrm{H}_{2} \mathrm{O} 0,1 \mathrm{~g}, \mathrm{KCl} 0,2$ g, Glucosa $10 \mathrm{~g}$, Yeast Extract 0,5 g, $\mathrm{MnSO}_{4}$ dan $\mathrm{FeSO}_{4}$ sedikit, Agar $20 \mathrm{~g}$, Aquadest 1000 $\mathrm{ml}$, dengan $\mathrm{pH} 6,8$.

\subsection{Isolasi bakteri pelarut fosfat}

Isolasi dilakukan dengan cara pengenceran, sebanyak $1 \mathrm{~g}$ sampel tanah dimasukkan dalam $9 \mathrm{ml}$ larutan garam fisiologis $(\mathrm{NaCl} 0,85 \%)$ dalam tabung reaksi kecil, kemudian divortek, dibuat seri pengenceran dengan cara memipet larutan sebanyak $1 \mathrm{ml}$ dimasukkan kedalam 9 ml larutan $\mathrm{NaCl} 0,85 \%$, dan seterusnya sampai diperoleh seri pengenceran $10^{-1}-10^{-7}{ }^{14}$, dipipet $0,1 \mathrm{ml}$ dituangkan dalam petridish yang telah berisi media Pycosvkaya tersebut diatas, dan diratakan dengan spatula, kemudian diinkubasikan pada suhu kamar $\left(27-28^{\circ} \mathrm{C}\right)$, setiap hari diamati pertumbuhannya dan dihitung jumlah koloninya. Penghitungan jumlah koloni dilakukan dengan metode cawan hitung (plate count) ${ }^{15)}$. Isolat yang didapat dipindahkan dalam media Pycosvkaya dalam tabung reaksi miring, kemudian dimurnikan sampai mendapatkan isolat yang murni (yang terdiri dari 1 koloni).

\subsection{Pemurnian dan Karakterisasi}

Pemurnian dilakukan dengan cara koloni diambil dengan Ose dimasukkan dalam aquadest steril $(5 \mathrm{ml})$, kemudian divortek, dipipet $0,1 \mathrm{ml}$ dimasukkan dalam petridish yang berisi media Pycosvkaya padat, diratakan dengan spatula, kemudian diinkubasikan pada suhu kamar $\left(27-28^{\circ} \mathrm{C}\right)$, koloni yang tumbuh (yang terdiri dari 1 koloni) ditanam dalam media Pycosvkaya miring dalam tabung reaksi (sebagai kultur murni). Untuk karakterisasi isolat tersebut ditumbuhkan pada media Pycosvkaya dalam petridish, diinkubasikan pada suhu kamar, kemudian diamati untuk melihat kemampuannya dalam melarutkan fosfat, yang akan ditandai zona berwarna bening atau terang disekeliling koloni ${ }^{16)}$.

\section{HASIL DAN PEMBAHASAN}

Sampel tanah dari desa Suro Muncang, Kecamatan Ujan Mas, Kabupaten Kapahiang, Propinsi Bengkulu sebanyak 15 sampel. Populasi bakteri pelarut fosfat berkisar antara $13-76 \times 10^{5} \mathrm{CFU} / \mathrm{g}$, hasil tertinggi diperoleh pada sampel tanah dari perakaran tanaman Melinjo (Gnetum gnemon), dan (Tabel 1).

Sampel tanah dari desa Bukit Peninjauan, Kecamatan Sukaraja, Kabupaten Seluma, Propinsi Bengkulu sebanyak 10 sampel. Populasi bakteri pelarut fosfat berkisar antara $29-101 \times 10^{5}$ $\mathrm{CFU} / \mathrm{g}$, hasil tertinggi diperoleh pada sampel tanah dari perakaran tanaman Semangka (Citrulus lanatus) (Tabel 2).

Populasi bakteri pelarut fosfat yang diperoleh sangat bervariasi pada masingmasing perakaran tanaman, hal ini disebabkan karena perkembangan jasad renik didalam tanah sangat dipengaruhi oleh aktivitas metabolisme akar tanaman yaitu tanaman melakukan aktivitas metabolisme akar yang mengeluarkan senyawa metabolit kedalam tanah melalui akar yang disebut eksudat. Eksudat tersebut pada masing-masing tanaman komposisinya berbeda-beda. Eksudat ini dikeluarkan oleh akar tanaman kedalam tanah yang akan dimanfaatkan oleh bakteri didalam tanah, yang mana bakteri tersebut akan dapat bertahan hidup dan memperbanyak diri,sehingga akan mempengaruhi populasi dan keragaman mikroorganisme pelarut fosfat di tanah sekitar perakaran Seperti yang dikatakan ${ }^{17)}$ bahwa aktivitas metabolisme dan senyawa 
metabolit yang dilepaskan oleh tanaman melalui akar merupakan faktor yang sangat menentukan keberadaan mikroorganisme tanah pada daerah perakaran tanaman, pada umumnya aktivitas bakteri tanah akan meningkat semakin dekat dengan permukaan akar tanaman yang masih dipengaruhi oleh aktivitas metabolisme akar tanaman

Tabel 1: Populasi bakteri tanah dari desa Suro Muncang, Kecamatan Ujan Mas, Kabupaten Kapahiang, Propinsi Bengkulu.

\begin{tabular}{|ll|l|c|c|}
\hline No sampel & \multicolumn{1}{|c|}{ perakaran tanaman } & \multicolumn{2}{|c|}{ Populasi bakteri pelarut fosfat (CFU X $\left.10^{5}\right) / \mathrm{g}$ tanah } \\
\hline & & & bakteri pelarut fosfat & jumlah isolat \\
\hline 1 & BKL & Jagung (Zea mays) & 56 & 3 \\
\hline 2 & BKL & Pisang (Musa paradisiaca) & 61 & 3 \\
\hline 3 & BKL & Singkong (Manihot utilissima) & 48 & 3 \\
\hline 4 & BKL & Alpukat (Persia americana Mill) & 33 & 3 \\
\hline 5 & BKL & Jeruk (Citrus sp.) & 32 & 3 \\
\hline 6 & BKL & Kedondong (Spondias sp.) & 17 & 3 \\
\hline 7 & BKL & Merica (Piper nigrum) & 23 & 3 \\
\hline 8 & BKL & Melinjo (Gnetum gnemon) & 76 & 3 \\
\hline 9 & BKL & Gamal (Glyciridia sp.) & 67 & 3 \\
\hline 10 & BKL & Buncis (Vigna sinensis) & 19 & 3 \\
\hline 11 & BKL & Kopi (Coffea sp.) & 42 & 3 \\
\hline 12 & BKL & Pepaya (Carica papaya) & 56 & 3 \\
\hline 13 & BKL & Dadap (Erythrina sp.) & 18 & 3 \\
\hline 14 & BKL & Padi (Oryza sativa) & 44 & 37 \\
\hline 15 & BKL & Hutan lindung Saba Penanjung & & 3 \\
\hline
\end{tabular}

Tabel 2: Populasi bakteri tanah dari desa Bukit Peninjauan, Kecamatan Sukaraja, Kabupaten Seluma, Propinsi Bengkulu.

\begin{tabular}{|l|l|c|c|}
\hline No sampel & perakaran tanaman & \multicolumn{2}{|c|}{ populasi bakteri pelarut fosfat (CFU X 105)/g tanah } \\
\hline & & bakteri pelarut fosfat & jumlah isolat \\
\hline $16 \mathrm{BKL}$ & Padi (Oryza sativa) & 59 & 3 \\
\hline $17 \mathrm{BKL}$ & Jagung (Zea mays) & 52 & 3 \\
\hline $18 \mathrm{BKL}$ & Semangka (Citrulus lanatus) & 101 & 3 \\
\hline $19 \mathrm{BKL}$ & $\begin{array}{l}\text { Lamtoro (Leucaena } \\
\text { leucocephala) }\end{array}$ & 96 & 3 \\
\hline $20 \mathrm{BKL}$ & Pisang (Musa paradisiaca) & 63 & 3 \\
\hline $21 \mathrm{BKL}$ & tanpa tanaman & 72 & 3 \\
\hline $22 \mathrm{BKL}$ & Kelapa sawit (Elais guinensis) & 51 & 3 \\
\hline $23 \mathrm{BKL}$ & Ubi jalar (Ipomea batatas) & 63 & 3 \\
\hline $24 \mathrm{BKL}$ & Karet (Hevea brasilensis) & 29 & 3 \\
\hline $25 \mathrm{BKL}$ & Singkong (Manihot utilissima) & 41 & \\
\hline
\end{tabular}


tersebut ${ }^{18)}$ melaporkan bahwa jumlah dan tipe perakaran serta spesies tanaman yang berbeda mempunyai komposisi eksudat yang berbeda pula, serta eksudat yang dikeluarkan oleh akar tanaman tergantung pada umur tanaman dan fase pertumbuhan tanaman. Selain itu akar tanaman mengeluarkan eksudat yang terdiri dari senyawa-senyawa gula seperti asam amino, asam organik, glikosida, senyawa-senyawa nucleotida dan basanya, enzim, vitamin, dan senyawa indole yang merupakan hasil metabolisme yang dikeluarkan oleh tanaman melalui akar, akan sangat menentukan populasi jasad renik didalam tanah, serta faktor kesuburan tanah, reaksi tanah $(\mathrm{pH})$, kandungan $\mathrm{O}_{2}$, ketersediaan energi dan sumber hara, serta kondisi fisik, kimia, biologi, dan lingkungan sangat mempengaruhi populasi jasad renik didalam tanah ${ }^{19,20,21)}$.

Setelah dilakukan pemurnian didapatkan isolat bakteri pelarut fosfat sebanyak 75 isolat murni, dari 75 isolat yang didapat, setelah dilakukan karakterisasi dengan cara menumbuhkan isolat dalam media Pycosvkaya padat menunjukkan bahwa adanya zona bening disekitar koloni, hal ini menunjukkan bahwa daerah bening disekitar koloni pada isolat tersebut merupakan tanda adanya aktivitas bakteri pelarut fosfat dalam melarutkan $\mathrm{P}$ terikat, hal ini terjadi karena adanya pelarutan $\mathrm{Ca}_{3}\left(\mathrm{PO}_{4}\right)_{2}$ yang ada didalam media Pycosvkaya padat. Mekanisme pelarutan fosfat tersebut diyakini melalui proses yang sangat komplek melibatkan metabolisme sel yang menghasilkan senyawa organik seperti asam glukonat, sitrat, laktat, dan aktivitas oksidasi reduksi sel, terutama yang berhubungan dengan assimilasi $\mathrm{NH} 4+$ dan pelepasan proton oleh aktivitas respirasi. Pelarutan fosfat didalam tanah juga melibatkan dua enzim utama yaitu phosphatase basa dan phosphatase asam 22,23), Seperti yang dikemukakan oleh ${ }^{24)}$ bahwa zona bening disekitar koloni bakteri pelarut fosfat secara kualitatif menunjukkan besar kecilnya kemampuan bakteri tersebut dalam melarutkan $\mathrm{P}$ dari fosfat tidak larut. Pembentukan zonasi bervariasi dari masingmasing isolat, mulai terbentuk pada hari ke 2 sampai hari ke 8 , belum diketahui apakah pembentukan zonasi yang lebih cepat akan mempunyai kemampuan melarutkan fosfat yang lebih tinggi pula, hal ini memerlukan penelitian lebih lanjut.

\section{KESIMPULAN}

Dari hasil penelitian dapat disimpulkan bahwa jumlah bakteri pelarut fosfat pada kedua desa sangat bervariasi. Jumlah bakteri berkisar antara 13-101 X $10^{5}$ CFU/g tanah dan jumlah tertinggi pada contoh tanah daerah perakaran tanaman semangka (Citrulus lanatus). Didapatkan isolat sebanyak 75 isolat, semuanya mampu melarutkan fosfat, zonasi terbentuk pada hari ke 2 sampai dengan hari ke 8 .

\section{DAFTAR PUSTAKA}

1. Schottendreier. M and U. FalkengrenGreup. 1999. Plant induced alteration in the rhizosphere and the utilization of soil heterogenicity. Plant Soil. 209: 297-309.

2. Schroder. P and A. Hartmann, 2003. New Developments in Rhzosphere Research. J. Soils \& Sediments 3 (4); 227.

3. Alexander. M. 1977. Soil Microbiology. 2 nd ed. John Wiley and Sons. Inc. New York. 472 p.

4. Kundu. B.S and A.C. Gaur. 1980. Establishment of Nitrogen fixing and phosphate solubilizing bacteria in rhizosphere and their effect on yield and nutrient uptake of wheat crop. Plant and Soil. 57: 223-230.

5. Gaur.A.C; R.S. Mather and K.V. Sadasivam. 1980. Effect of organic material and phosphate-dissolving culture on the yield of wheat and greengram. Indian J. Agron. 25: 501-503.

6. Pal. S.S, 1998. Interaction of an acid tolerant strain of phosphate solubilizing 
bacteria with a few acid tolerant crops. Plant and Soil. 198: 167-177.

7. Goos. R.E, B.E. Johnson and R.W. Stack. 1994. Penicellium biliji and phosphorus fertilization effects on the growth, development yield, and common root seventy of spring wheat. Fertilizer Research. 39: 97-103.

8. Singh. S and K.K. Kapoor. 1998. Effect of inoculation of phosphatase solubilizing microorganism and arbuscular mycorrhizal fungus on mungbean grown under natural soil condition. Mycorrhiza. 7: 249-253.

9. Young. C.C., C.L. Chen \& C.C. Chao. 1990. Effect of Rhizobium, vesicular arbuscular mycorrhiza and phosphate solubilizing bacteria on yield and mineral phosphorus uptake of crops in subtropical-tropical soils. Trans Int. Congr. Soil. Sci. 14th August 12-18. 1990. Kyoto, Japan. p: 55-60.

10. Kucey. R.M.N. 1987. Increased phosphorus uptake by wheat and field beans inoculated with a phosphorussolubilizing Penicillium biliji Strain and with vesicular-arbuscular mycorrhizal fungi. Applied and Environ Microbiol. 53: 2699-2703.

11. Illmer. P and F. Schiner. 1992. Solubilization of organic phosphate by microorganism isolated from forest soil. Soil Biol Biochem. 24: 389-395.

12. Glick. B.R. 1995. The Enhancement of Plant by Free Living bacteria. Can. J. Microbiol. 41: 109-117

13. Sundara Rao. W.V and W.K. Sinha. 1963. Phosphate Dissolving Microorganism in the Soil and Rhizosphere. Indian. J. Agric. Sci. 33: 272-278.

14. Anas. I. 1989. Biologi Tanah dalam Praktek. Departemen Pendidikan dan Kebudayaan. Direktorat Jendral Pendidikan tinggi. Pusat Antar Universitas Biotehnologi. Institut Pertanian Bogor, Bogor. $161 \mathrm{~h}$.

15. Lay. B.W. 1994. Analisis Mikroorganisme di Laboratorium. P.T. Raja Grafindo
Persada. $168 \mathrm{~h}$.

16. Das. A.C. 1963. Utilization of Insoluble Phosphate by Soil fungi. J. Indian Soc. Soil. Sci. 11: 203-207.

17. Gibson.A.H. 1985. Current Perpectves in Nitrogen Fixation. Proceeding of The fourth International Symposium on Nitrogen Fixation. Aust. Academy of Sci.534 p.

18. Kato, K., Y. Arima and H. Hirata. 1997. Effect of exudates released from seed and seeding root of common bean (Phaseolus vulgaris $L$ ) on proliferation of Rhizobium sp. (Phaseolus) Soil Sci.. Plat Nutr. 43: 275-283.

19. Alagawadi. A.R and A.C. Gaur. 1988. Assosiative Effect of Rhizobium and Phosphate Solubilizing Bacteria on the yield an Nutrien Uptake of Chickpea. Plant and Soil. 105:241-246.

20. Sorensen. J; J.D. Van Elsas and J.T. Trevors. 1997. The rhizosphere as a habitat for soil microorganism. In: E.M.H. Wellington (ed) Modern Soil Micribilogy. Marcel Dekker. New York. P: 21-45.

21. Walker. T.S; H.P. Bais; E. Grotewold and J.M. Vivanco. 2003. Root Exudation and rhizosphere biology. Plant Pysiol. 132: 49-51.

22. Lee. M., Breckmidge. C and Knowles. 1970. Effect of same culture condition on the Production of the Jurnal Indole-3Acetic Acid and Giberelin Like Subtance by Azotobacter vinelandii. Microbiology. 16: 1325 .

23. Kanti. A dan I.M. Sudiana. 2006. Diversitas bakteri Rhzisphere dari beberapa Tanaman di Gunung Merapi. Laporan Tehnik. Puslit Biologi-LIPI. h: 954-960.

24. Rachmiati. Y. 1995. Bakteri pelarut fosfat dari rizosfer tanaman dan memapuannya melarutkan fosfat. Prosiding Konggres Nasional IV HITI. Jakarta 12-15 Desember 1995. 
Tabel 3: Kemampuan melarutkan fosfat dari 45 isolat murni dari sampel tanah desa Suro Muncang, Kecamatan Ujan Mas, Kabupaten Kapahiang, Propinsi Bengkulu

\begin{tabular}{|c|c|c|}
\hline Nomor isolat & lokasi & Zonasi (hari ke) \\
\hline 1 BKLP (1) & Suro Muncang, Ujan Mas, Kapahiang, Bengkulu & 5 \\
\hline $1 \quad \operatorname{BKLP}(2)$ & Suro Muncang, Ujan Mas, Kapahiang, Bengkulu & 4 \\
\hline $1 \quad \mathrm{BKLP}(3)$ & Suro Muncang, Ujan Mas, Kapahiang, Bengkulu & 3 \\
\hline 2 BKLP (1) & Suro Muncang, Ujan Mas, Kapahiang, Bengkulu & 4 \\
\hline 2 BKLP (2) & Suro Muncang, Ujan Mas, Kapahiang, Bengkulu & 3 \\
\hline $2 \operatorname{BKLP}(3)$ & Suro Muncang, Ujan Mas, Kapahiang, Bengkulu & 5 \\
\hline $3 \quad B K L P(1)$ & Suro Muncang, Ujan Mas, Kapahiang, Bengkulu & 6 \\
\hline $3 \quad B K L P(2)$ & Suro Muncang, Ujan Mas, Kapahiang, Bengkulu & 8 \\
\hline $3 \quad \mathrm{BKLP}(3)$ & Suro Muncang, Ujan Mas, Kapahiang, Bengkulu & 7 \\
\hline $4 \quad \operatorname{BKLP}(1)$ & Suro Muncang, Ujan Mas, Kapahiang, Bengkulu & 4 \\
\hline $4 \quad \operatorname{BKLP}(2)$ & Suro Muncang, Ujan Mas, Kapahiang, Bengkulu & 3 \\
\hline $4 \quad B K L P(3)$ & Suro Muncang, Ujan Mas, Kapahiang, Bengkulu & 6 \\
\hline $5 \quad$ BKLP (1) & Suro Muncang, Ujan Mas, Kapahiang, Bengkulu & 3 \\
\hline $5 \quad \operatorname{BKLP}(2)$ & Suro Muncang, Ujan Mas, Kapahiang, Bengkulu & 5 \\
\hline $5 \quad \mathrm{BKLP}(3)$ & Suro Muncang, Ujan Mas, Kapahiang, Bengkulu & 7 \\
\hline $6 \quad \mathrm{BKLP}(1)$ & Suro Muncang, Ujan Mas, Kapahiang, Bengkulu & 4 \\
\hline $6 \operatorname{BKLP}(2)$ & Suro Muncang, Ujan Mas, Kapahiang, Bengkulu & 6 \\
\hline $6 \quad \mathrm{BKLP}(3)$ & Suro Muncang, Ujan Mas, Kapahiang, Bengkulu & 3 \\
\hline $7 \quad$ BKLP (1) & Suro Muncang, Ujan Mas, Kapahiang, Bengkulu & 4 \\
\hline $7 \quad \mathrm{BKLP}(2)$ & Suro Muncang, Ujan Mas, Kapahiang, Bengkulu & 7 \\
\hline $7 \quad \mathrm{BKLP}(3)$ & Suro Muncang, Ujan Mas, Kapahiang, Bengkulu & 4 \\
\hline 8 BKLP (1) & Suro Muncang, Ujan Mas, Kapahiang, Bengkulu & 8 \\
\hline $8 \quad B K L P(2)$ & Suro Muncang, Ujan Mas, Kapahiang, Bengkulu & 3 \\
\hline 8 BKLP (3) & Suro Muncang, Ujan Mas, Kapahiang, Bengkulu & 6 \\
\hline $9 \quad \mathrm{BKLP}(1)$ & Suro Muncang, Ujan Mas, Kapahiang, Bengkulu & 4 \\
\hline $9 \quad \mathrm{BKLP}(2)$ & Suro Muncang, Ujan Mas, Kapahiang, Bengkulu & 7 \\
\hline $9 \quad \mathrm{BKLP}(3)$ & Suro Muncang, Ujan Mas, Kapahiang, Bengkulu & 5 \\
\hline $10 \mathrm{BKLP}(1)$ & Suro Muncang, Ujan Mas, Kapahiang, Bengkulu & 2 \\
\hline $10 \mathrm{BKLP}(2)$ & Suro Muncang, Ujan Mas, Kapahiang, Bengkulu & 4 \\
\hline $10 \mathrm{BKLP}(3)$ & Suro Muncang, Ujan Mas, Kapahiang, Bengkulu & 5 \\
\hline $11 \mathrm{BKLP}(1)$ & Suro Muncang, Ujan Mas, Kapahiang, Bengkulu & 8 \\
\hline $11 \mathrm{BKLP}(2)$ & Suro Muncang, Ujan Mas, Kapahiang, Bengkulu & 4 \\
\hline $11 \mathrm{BKLP}(3)$ & Suro Muncang, Ujan Mas, Kapahiang, Bengkulu & 3 \\
\hline 12 BKLP (1) & Suro Muncang, Ujan Mas, Kapahiang, Bengkulu & 5 \\
\hline $12 \operatorname{BKLP}(2)$ & Suro Muncang, Ujan Mas, Kapahiang, Bengkulu & 6 \\
\hline $12 \mathrm{BKLP}(3)$ & Suro Muncang, Ujan Mas, Kapahiang, Bengkulu & 4 \\
\hline 13 BKLP (1) & Suro Muncang, Ujan Mas, Kapahiang, Bengkulu & 3 \\
\hline
\end{tabular}

Isolasi, Populasi dan Karakterisasi,... J.Tek. Ling. 13 (1): 101 - 108 


\begin{tabular}{|c|c|c|}
\hline Nomor isolat & lokasi & Zonasi (hari ke) \\
\hline 13 BKLP (2) & Suro Muncang, Ujan Mas, Kapahiang, Bengkulu & 7 \\
\hline 13 BKLP (3) & Suro Muncang, Ujan Mas, Kapahiang, Bengkulu & 5 \\
\hline 14 BKLP (1) & Suro Muncang, Ujan Mas, Kapahiang, Bengkulu & 4 \\
\hline 14 BKLP (2) & Suro Muncang, Ujan Mas, Kapahiang, Bengkulu & 6 \\
\hline 14 BKLP (3) & Suro Muncang, Ujan Mas, Kapahiang, Bengkulu & 3 \\
\hline 15 BKLP (1) & Suro Muncang, Ujan Mas, Kapahiang, Bengkulu & 7 \\
\hline 15 BKLP (2) & Suro Muncang, Ujan Mas, Kapahiang, Bengkulu & 4 \\
\hline 15 BKLP (3) & Suro Muncang, Ujan Mas, Kapahiang, Bengkulu & 5 \\
\hline
\end{tabular}

Tabel 4: Kemampuan melarutkan fosfat dari 30 isolat murni dari sampel tanah desa Bukit Peninjauan, Kecamatan Sukaraja, Kabupaten Seluma, Propinsi Bengkulu.

\begin{tabular}{|c|c|c|}
\hline Nomor isolat & lokasi & Zonasi (hari ke) \\
\hline $16 \operatorname{BKLP}(1)$ & Bukit Peninjauan, Sukaraja, Seluma, Bengkulu. & 6 \\
\hline $16 \operatorname{BKLP}(2)$ & Bukit Peninjauan, Sukaraja, Seluma, Bengkulu. & 5 \\
\hline $16 \operatorname{BKLP}(3)$ & Bukit Peninjauan, Sukaraja, Seluma, Bengkulu. & 3 \\
\hline $17 \operatorname{BKLP}(1)$ & Bukit Peninjauan, Sukaraja, Seluma, Bengkulu. & 7 \\
\hline 17 BKLP (2) & Bukit Peninjauan, Sukaraja, Seluma, Bengkulu. & 4 \\
\hline 17 BKLP (3) & Bukit Peninjauan, Sukaraja, Seluma, Bengkulu. & 5 \\
\hline $18 \mathrm{BKLP}(1)$ & Bukit Peninjauan, Sukaraja, Seluma, Bengkulu. & 6 \\
\hline $18 \quad \operatorname{BKLP}(2)$ & Bukit Peninjauan, Sukaraja, Seluma, Bengkulu. & 2 \\
\hline $18 \mathrm{BKLP}(3)$ & Bukit Peninjauan, Sukaraja, Seluma, Bengkulu. & 4 \\
\hline $19 \operatorname{BKLP}(1)$ & Bukit Peninjauan, Sukaraja, Seluma, Bengkulu. & 5 \\
\hline $19 \operatorname{BKLP}(2)$ & Bukit Peninjauan, Sukaraja, Seluma, Bengkulu. & 3 \\
\hline $19 \operatorname{BKLP}(3)$ & Bukit Peninjauan, Sukaraja, Seluma, Bengkulu. & 6 \\
\hline $20 \operatorname{BKLP}(1)$ & Bukit Peninjauan, Sukaraja, Seluma, Bengkulu. & 7 \\
\hline $20 \operatorname{BKLP}(2)$ & Bukit Peninjauan, Sukaraja, Seluma, Bengkulu. & 4 \\
\hline $20 \operatorname{BKLP}(3)$ & Bukit Peninjauan, Sukaraja, Seluma, Bengkulu. & 3 \\
\hline 21 BKLP (1) & Bukit Peninjauan, Sukaraja, Seluma, Bengkulu. & 5 \\
\hline $21 \quad B K L P(2)$ & Bukit Peninjauan, Sukaraja, Seluma, Bengkulu. & 7 \\
\hline $21 \quad B K L P(3)$ & Bukit Peninjauan, Sukaraja, Seluma, Bengkulu. & 6 \\
\hline $22 \operatorname{BKLP}(1)$ & Bukit Peninjauan, Sukaraja, Seluma, Bengkulu. & 4 \\
\hline $22 \operatorname{BKLP}(2)$ & Bukit Peninjauan, Sukaraja, Seluma, Bengkulu. & 3 \\
\hline $22 \operatorname{BKLP}(3)$ & Bukit Peninjauan, Sukaraja, Seluma, Bengkulu. & 2 \\
\hline $23 \quad \operatorname{BKLP}(1)$ & Bukit Peninjauan, Sukaraja, Seluma, Bengkulu. & 4 \\
\hline $23 \operatorname{BKLP}(2)$ & Bukit Peninjauan, Sukaraja, Seluma, Bengkulu. & 5 \\
\hline 23 BKLP (3) & Bukit Peninjauan, Sukaraja, Seluma, Bengkulu. & 7 \\
\hline $24 \quad B K L P(1)$ & Bukit Peninjauan, Sukaraja, Seluma, Bengkulu. & 6 \\
\hline $24 \quad B K L P(2)$ & Bukit Peninjauan, Sukaraja, Seluma, Bengkulu. & 3 \\
\hline $24 \quad \mathrm{BKLP}(3)$ & Bukit Peninjauan, Sukaraja, Seluma, Bengkulu. & 4 \\
\hline 25 BKLP (1) & Bukit Peninjauan, Sukaraja, Seluma, Bengkulu. & 5 \\
\hline $25 \quad \operatorname{BKLP}(2)$ & Bukit Peninjauan, Sukaraja, Seluma, Bengkulu. & 2 \\
\hline $25 \quad B K L P(3)$ & Bukit Peninjauan, Sukaraja, Seluma, Bengkulu. & 3 \\
\hline
\end{tabular}

